\title{
Professional identity versus gender identity: Empirical study among top-level leaders and managers in Hungarian sport
}

\section{Szakmai identitás versus nemi identitás: Empirikus vizsgálat felső szintú magyar sportvezetök és sportmenedzserek körében}

\author{
Gyöngyi Szabó Földesi, Andrea Gál \\ University of Physical Education, Budapest, Department of Social Sciences
}

\begin{abstract}
Extensive literature supports the statement according to which in most countries there are much fewer women in leading position in sport than men. In Hungary the situation is rather unfavourable in this context; in the national sports federations and major sport clubs this proportion is only around ten per cent. The objective of this paper is to discuss the potential reasons for this kind of gender inequality from the perspectives of professional and gender identity. The study is based on an empirical research carried out among upperlevel sport leaders and sport managers with the help of qualitative methods. The data were collected by semi structured interviews ( $N=16$, eight men and eight women). The findings suggest that the two genders' views about themselves as sport leaders and managers are different since they are built on different values and experiences. Females' professional identity seems to be stronger than men's; only women with high organizational commitment to sport accept such status. Men believe that they are natural born leaders and consider their leading roles as evident. It is concluded that with males gender identity dominates including their macho approach to sport; with women professional identity precedes gender identity and leads to the over fulfilment of their professional and managerial tasks. The gender composition of top-level managers has been changing very slowly in Hungarian society at large, but it has been modified even more slowly in sport. Sport leadership is often regarded as gendered profession in Hungary, positive trends have not yet made their mark on this side of the world.
\end{abstract}

Keywords: multiple identities, gender inequality, organizational commitment

\begin{abstract}
Absztrakt - Gazdag szakirodalom igazolja azt a megállapítást, mely szerint a legtöbb országban lényegesen kevesebb nő van vezető pozícióban a sportban, mint férfi. Magyarországon a helyzet ebból a szempontból meglehetósen kedvezótlen. A nemzeti sportszövetségekben és a nagy sportklubokban ez az arány mindössze tíz százalék körül van. A dolgozat célja a nemek közötti egyenlótlenség okainak vizsgálata a szakmai és a nemi identitás aspektusából. A tanulmány empirikus vizsgálatra épül, amelyet a szerzők felső szintú sportvezetők és sportmenedzserek körében végeztek kvalitatív módszerekkel ( $\mathrm{N}=16$, nyolc férfi és nyolc nó). Az adatgyújtést félig strukturált interjúval folytatták. Az eredmények azt mutatják, hogy a férfiak és nók nézetei saját státusukról mint sportvezetókról, illetve sportmenedzserekról, eltérő, miután különböző társadalmi értékekre és tapasztalatokra épül. A nők szakmai identitása erősebbnek túnik, mint a férfiaké; csak azok a nők vállalnak ilyen jellegú munkát, akiknek elkötelezettsége a sport iránt rendkívül erős. A férfiak azt hiszik, hogy ők született vezetők, és nyilvánvalónak tekintik, hogy ók töltik be a vezetó szerepeket a sportban. Következtetéseikben a szerzók megállapítják, hogy a sportban a férfi vezetőknél macsó szemleletükre épülő nemi identitásuk dominál; nőknél a szakmai identitás megelőzi a nemi identitást, és ez nem ritkán feladataik túlteljesítéséhez vezet. A felső szintú vezető́k nemi összetétele lassan módosul a magyar társadalomban, a sportban azonban még ettól is lassabbak a változások. A sportvezetést gyakran még mindig nemhez kötött foglalkozásnak tekintik Magyarországon, a pozitív trendek begyúrúzése még várat magára.
\end{abstract}

Kulcsszavak: többszörös identitás, nemi egyenlótlenség, szervezeti elkötelezettség 


\section{Introduction}

Since Heilman, Block and Martell's (1995) often quoted paper was published, multiple empirical research supported the idea that gender stereotypes influence most people's perception about managers and leaders: when thinking of them, they think of males or persons with masculine characteristics. The view "think of manager-think of male" seems to be a global phenomenon. This situation can be observed in sport, as well.

Extensive literature supports the statement according to which in most countries there are fewer women in leadership position in sport than men. This declaration has been recently underlined by several papers written by 27 well-known authors from 15 different nationalities, and published in a thematic volume entitled: Gender Diversity in European Sport Governance (Elling, Hovden and Knoppers, 2019). However, there are considerable differences between the individual continents and countries in this respect. According to the most recent studies, the expression of "fewer women" means different percentages in different countries. For instance, in Sweden at the National Sport Confederation $44 \%$ of the active members are women, and 56\% of them are men (Norberg, 2017, quoted by Norberg and Hedenborg, 2019), while in Poland, data from 2016 revealed "that women constitute only $12 \%$ (45) of the 377 members of Olympic sports federation boards and $11 \%$ (13) of the 123 management directors." (Jakubowska, 2019:63).

In Hungary the situation in this context is rather unequal. Becoming a leader is hard to accomplish; it is a long way similar to a labyrinth full of complications (Eagly and Carli, 2007). In Hungary, the process was even more difficult than in truly modern countries, since it has been a patriarchal society. Men held power for long; they predominated in the most important roles not only in sport but in all other social sub-systems. Political economic, legal, cultural, education, communication, etc. sectors had been governed mostly by men. Regardless of the nature of political power there had been mainly declarations about gender equality, but women's inferior position, especially their share in governance hardly changed. When at the last political system change in 1990 a new gender pattern was introduced, women faced almost the same old inequalities. While more women were able to advance to middle level position than earlier, very few of them could break the so called glass ceiling (Gal and Foldesi, 2019).

Many men's conviction according to which sport is a "male preserve" (Dunning, 1994) made matters even worse in the field of sport as far as gender-role stereotypes and women's underrepresentation in leadership positions are concerned.

The latest studies have shown that in spite of the increasing number of Hungarian women in sport over the last decades (Gal, 2007; Gal et al., 2008), they continue to play a subordinate role in sport organizations compared to their male counterparts, as far as decision-making positions are concerned. Key positions in Hungarian sport have traditionally been occupied by men; a few spectacular administrative endeavours did not result in serious changes. At the end of 2017, the ratio of women in sport governance was very low: the number of upper-level managers was six percent and the rate of upper middle-level managers was around 10\% (Gal and Foldesi, 2019).

This paper discusses this type of gender inequality from the perspectives of gender identity and professional identity among both men and women in sport. Its major objective is to discover the ongoing imbalance between men and women regarding the maintenance of power relations. It is based on an empirical examination which attempted to give answers to the following research questions:

- Do sport leadership and management have gender-related attributes according to role expectations?

- How do female and male sport leaders and managers perceive themselves within their occupational context? Are there any gender and/ or professional differences between sport leaders and sport managers on this point?

- How do women and men sport leaders and managers communicate their occupation to others? Are there any gender or/and professional differences between them on this point?

- What is the relationship between professional and gender identity with regards to the two genders among leaders and managers in sport?

\section{Theoretical background}

Different disciplines, such as philosophy, psychology, social psychology, sociology, cultural anthropology, approach to the concept of people's identities in different ways. Accordingly, social 
scientists may identify several different types of identity, and it is agreed among them that a person may hold multiple identities. Out of multiple identities the focus of this paper is on professional and on gender identity.

The theoretical starting point of our study was to clarify these two terms. From among the rich possibilities, the following definitions were chosen for our research purposes:

"Professional identity is the concept which describes how we perceive ourselves within our occupational context and how we communicate this to others. [...] What I call myself defines who I am." (Neary, 2014:14). Analysing Beijaard et al.'s research Neary also emphasizes that "Professional identity is not static but fluid; it is strongly influenced by how we see ourselves, how we perceive others perceive us and how we are viewed by society at large" (Neary, 2014:15).

According to Morrow and Messinger (2006:8) "Gender identity refers to an individual's sense of identity as masculine or feminine, or some combination thereof." The latter is called androgynous gender identity. Many androgynous individuals identify themselves as gender-neutral or non-binary. Attempts to measure psychological androgyny and to discuss a new type of sex role inventory were made as early as the 1970s (Bem, 1974).

Gender identity is often defined in reference to gender role. "Gender identity is defined as a personal conception of oneself as male or female (or rarely, both or neither). This concept is intimately related to the concept of gender role, which is defined as the outward manifestations of personality that reflect the gender identity. Gender identity in nearly all instances, is self-identified, as a result of a combination of inherent extrinsic and extrinsic environmental factors; gender role, on the other hand is manifested within society by observable factors such as behaviour and appearance." (Ghosh, 2015:1).

The above definitions helped facilitate to studying the people's attitudes towards them.

On the other hand, to define theoretically further key terms employed in our research led to dilemmas. Namely, it caused difficulties to make a distinction between leadership and management since the meaning of these two terms are very similar, they are often used interchangeably as synonyms. Their functions overlap each other indeed, and they require similar skills. It is true that regarding the two jobs, the quality of the activity is what really matters. However, we agree with John Kotter who underlined that it is inappropriate to use these two terms as synonyms because there are considerable differences between them. The distinction he made between management and leadership proved to be suitable for our research. He defined the terms in question as follows: "Management is a set of processes that keep an organization functioning. They make it work today - they make it hit this quarter's numbers. The processes are about planning, budgeting, staffing, clarifying jobs, measuring performances, and problem-solving when results did not go to plan. [...] Leadership is very different. It is about aligning people to the vision that mean buy-in and communication, motivation and inspiration." (Kotter, 1990, quoted by Ratcliffe, 2013.)

\section{Methods}

This study is based on an empirical research carried out among upper-level sport leaders and managers. Distinction was made between them based on their primary role in the given sport organization they were employed in. Experts with sportspecific knowledge were regarded as sport leaders (head coaches, sporting directors, etc.) while the dominant expert knowledge of sport managers was viewed to running sport organizations (presidents and general secretaries of big sport clubs, federations, associations, etc.).

The examined population was selected by quota sampling. The following characteristics were considered as bases of the quota: being employed in the job by a major sport organization for more than five years and to be younger than 50 years. Four male and four female sport leaders and four male and four female sport managers were selected for the purpose.

Data were gathered by semi-structured interviews $^{1}$ the guideline of which paid particular attention to understanding sport leaders' and managers' perceptions about their profession and their identification with it. The findings were analysed according to the following dimensions based on

${ }^{1}$ Beside the researchers, the following PhD students, qualified for making interviews, helped collecting the data: Zoltán Boros, Pál Csillag, Gábor Lehöcz, Ágnes Csordás-Maxin, Orsolya Moravecz, Péter Szabó, Zoltán Tánczos, Zsombor Zilinyi. 
the theoretical background: perceptions of role expectations, communicating occupational status, and gender identity versus professional identity. They are presented in the sub-chapters of the Results section, under the same headings.

\section{Results}

\section{Perceptions of role expectations}

The findings revealed that out of the interviewees the majority of female sport managers and somewhat fewer female sport leaders experienced that the expectations towards their role had gender-related attributes, more precisely, attributes which traditionally characterize men. They had the feeling that in order to carry out their job properly, they were expected to be determined, firm, independent, assertive, committed, (self-)respectful, balanced, (self)-confident, and categorical. According to gender stereotypes they were also supposed to talk less and act more, like men do. Since neither the majority of female sport leaders nor the female sport managers believed that they can be portrayed mainly by these personality characteristics, they perceived themselves within their occupational context as if they were in an exceptional position.

"I refuse the guess that I am a masculine type woman. I think that not only men but also women have the right to be independent and committed. I am not concealing how much I am committed to my sport, which gave me a lot, so now I try to return it." (Female sport federation leader)

The views of the interviewed female sport leaders' perception differed from each other depending on the sports they were involved in. Sport leaders in sports categorized traditionally as feminine sports (e.g. rhythmic gymnastics, aerobics, figure skating, artistic swimming) perceived their status nearly as gender-neutral and spoke about it in a similar way. While female sport leaders in sports categorized as masculine were rather ambivalent: some of them underestimated, some of them overestimated their importance in their position. In other words, some of them had an inferiority complex; some of them exaggerated the significance of their position.

Female sport leaders' perception of their professional status in two-gender sports depended on whether they were talking about sports long-established also for women (e.g. basketball, track and field, swimming) or about sports accepted internationally for women relatively not long ago (e.g. water polo, football, boxing). When they talked about the latter, their views were similar to many female sport managers' who saw themselves as if they were in an unusual status where they have to prove more than men that they are capable to perform.

As a result of their perceived role expectations, the female sport managers interviewed had rather inconsistent ideas of their professional situation. In a special manner, occasionally they were proud of their own achievements, another time they were deeply dissatisfied with the results of their efforts.

Notwithstanding, a few interviews referred to positive changes in this field. Namely, there were both male and female interviewees who noticed less stereotypes and preconception against women being in decision making positions in closely sport related issues. At the same time, out of the 16 interviewees neither men nor women expected females to be successful managers.

"In my sport clubs there are female sport leaders who are treated as equal with men by everybody. Although, they approach professional issues differently, they work as efficiently and as fair as their male fellow do. However, it is without any doubt that they are not good managers, because they are too emotional." (Male head coach)

„According not only to my own judgment but also to many men's, I am an outstanding top manager in sport, so I have the chance to study closely other female sport managers. I have to confess, that the majority of them are not especially talented in this work. I know, it is not a popular viewpoint but I take the risk for holding it: I am against increasing women's representation in sport management." (Female managing director)

\section{Communicating occupational status}

During our research women and men as well as sport leaders and sport managers communicated their occupational status to others in quite different ways. The biggest differences were found within the individual groups, not between them. On the one hand, there were also gender differences in this regard. Generally speaking, female respondents communicated their occupation to others emphasizing the term sport in the compound word, while males put more stress on the expressions of leaders 
or managers. On the other hand, when female respondents named their occupation, roughly half of them mentioned their responsibility in connection with their role.

"I am responsible for coaching the 14-18 agegroups. In principle I can educate them. However, in reality, I have to maximize the kids' performances." (Female head coach)

"As a manager, my duty is to solve all problems which would prevent the national team from achieving its potential. In other words, I have to overcome all the obstacles that they might invariably face on their way. It is hard work and not always gratifying." (Female sport manager)

The research subjects' business cards also supported the above statements. The few women who had it at all, always registered on their business card that they are from sport governance. Most men had business cards on which they called themselves directors, managers, heads of departments etc., and only the address of their workplace showed that they were from sport.

From the fact how female and male sport leaders and managers called themselves in their occupational context it also turned out that they often despised each other's job. Several sport leaders in the research population were of the opinion that it is just fashionable to maintain that the key persons in any sport organizations are the managers, efficiency depends on them. In contrast, they were convinced that they, the sport leaders are the ones, who play key roles, since the potential successful "products", the athletes are in their hands. They believed that sport in today's Hungary is overmanaged and under-led. Opposing these views, some sport managers reproached sport leaders for not demonstrating their solidarity in case of necessity. They lacked it because from their point of view it would be a matter of mutual interest.

\section{Gender identity versus professional identity}

The findings suggest that the relationship between professional identity and gender identity with female and male sport leaders and managers is different. Males can be characterized by professional-gender identity integration. Women seem to have professional identity above their gender identity.

In the mirror of the interviews, both male sport leaders and managers see themselves as if they were in the right place and sometimes overestimate their importance to the detriment of women.

"I am OK, I like what I do. I cannot imagine that a woman would be able to do the work that I do every day. To be honest, I do not like at all to see women employed in male sports. Maybe they can coach children with whom I would not have enough patience, anyway." (Male sport leader)

Women's frequent reaction to the men's common attitudes is to prove that they are capable, which means that they work much more than men. Some male research subjects are convinced that it would not be necessary and they admit the valuable activity of certain women in sport, especially in coaching junior athletes.

„As I see, there are fewer prejudices against women working in sport governance than it was in the past. For instance, the current state secretary is not only pretty, but she does her job correctly and efficiently." (Male sport manager)

In general, both female and male sport leaders' identification with the sport organization which they are employed at seems to be very strong. Occasionally it appears to be stronger than their gender identification. But some male sport managers seem to identify themselves less with their sport organization than female sport managers do. Regardless of the nature of their post, the majority of the female interviewees think that it is very difficult to harmonize gender identity with professional identity. They are of the opinion, rightly or wrongly, that if they behave in their workplace "like women" they might lose professional prestige. Some of them even believe that they would create unhealthy environment, even conflicts in their sport organization, with feminine style of communication or feminine style clothes, since some men could misunderstand them. The following quotations from two interviews illustrate well the above statement:

"I always have been determined, explicit, sometimes, maybe categorical, therefore I am labelled as masculine. I do not agree with this attribute, but to be honest, I do not mind it too much. I am sure that if I were a lady-type person, I would not have been selected for this job, my colleagues would not have accepted me as a manager and I would not have the same high prestige as hopefully I have among them." (Female sport manager)

"Generally speaking, I have no problem to work 
in such a male world as sport. However, when once at a social event I put on trendy clothes and I made up my face, I noticed that some men looked at me in a different way. One of them even approached me in an indecent way, of course, without being encouraged. And on the top of everything, he was offended!" (Female sport leader)

\section{Discussion and conclusion}

The fact that, as the above analysis shows, the two genders' views about themselves as sporting leaders and managers are different can be explained by the everyday social reality that their views are built on different values and experiences. As for female sport leaders and sport managers, their professional identity seems to be stronger than that of men. In our understanding only women with high organizational commitment to sport accept such status. As for men, they believe that they are natural born leaders and consider their leading roles as evident. They are certain of the rightfulness of their top priority in sport leadership. In part, they learnt this behavioural pattern in other subsystems and in society as a whole. In part, their gender identity, sometimes unconsciously and/or indirectly involves a macho philosophy which is widely accepted in sport, according to which only men have the right to manage sport. In this spirit they are convinced that sport needs them at least as much as they need sport, if not more.

According to our research findings, gender identity is also a relevant aspect of women's attitudes and organizational behaviour in sport but in a different manner. It is overshadowed by professional identity and plays a controversial role. Articulated gender identity might generate minority feelings for female sport leaders and managers. Their social environment can discourage them suggesting that they are not good enough, they are even incompetent for their position.

Based on the results of our research, it is concluded that gender identities manifest themselves in the sporting milieu in diverse ways with males and females: while both have multiple identities, the main difference is that with males, gender identity dominates in sport, based on their macho approach, including their assumed overwhelming superiority, whereas with women, professional identity proceeds gender identity and it leads to the over-fulfilment of their tasks.
Positive changes can be observed in Hungarian society related to women's situation in several social areas but very little shift occurred concerning their top managerial position. The gender composition of top-level managers has been changing very slowly in society at large, but it has been modified even more slowly in sport. Sport leadership is still regarded as a gendered profession in Hungary; positive trends have not made their mark on this side of the world.

\section{References}

1. Bem, S. L. (1974): The Measurement of Psychological Androgyny. Journal of Consulting and Clinical Psychology, 42: 155-162.

2. Dunning, E. (1994): Sport as a male reserve: Notes on the social sources of masculine identity and its transformation. In: Birrell, S. and Cole, C. L. (eds.) Women, sport, and culture. Human Kinetics Publisher. Champaign, IL. 163-179.

3. Eagly, A. H. and Carli, L. L. (2007): Through the labyrinth. The truth about how women become leaders. Harvard Business School Press, Boston.

4. Elling, A., Hovden, J. and Knoppers, A. (eds.) (2019) Gender Diversity in European Sport Governance. Routledge, Abingdon, Oxon.

5. Jakubowska, H. (2019): Poland: underrepresentation and misrecognition of women in sport leadership. In: Elling, A., Hovden, J. and Knoppers, A. (eds.) Gender Diversity in European Sport Governance. Routledge, Abingdon, Oxon. 59-69.

6. Gal, A. (2007): Sport és társadalmi nem a 21. század elején a média tükrében Magyarországon [Sport and gender at the beginning of the $21 \mathrm{st}$ century in the mirror of the media in Hungary]. (Unpublished doctoral dissertation). Semmelweis Egyetem, Budapest.

7. Gal A., Kovacs, Á. and Velenczei, A. (2008): Sport, gender és média: a női és férfi sportolók megjelenítése a sajtóban. Szociológiai Szemle, 3:32-60.

8. Gal, A. and Foldesi, G. (2019): Hungary: unquestioned male dominance in sport governance. In Elling, A., Hovden, J. and Knoppers, A. (eds.) Gender Diversity in European Sport Governance. Routledge, Abingdon, Oxon. 70-80. 
9. Gosh, S. (2015): Gender identity. Medscape: Drugs and Diseases. Retrieved May 22, 2018 from Kotter, J. P. (1990/1999): What Leaders Really Do? Harvard Business Review book. Amazon, Boston. Retrieved November 3, 2018 from https://www.amazon.co/ Harward-business-review-Leadership/ 108758489

10. Heilman. M. E., Block, C. B. and Martell, R. F. (1995): Sex stereotypes: Do they influence perceptions of managers? Journal of Social Behaviour and Personality, 10:237-252.

11. Morrow, D. F. and Messinger, L. (eds.) (2006): Sexual Orientation and Gender Expression in Social Work Practice: Working with Gay Lesbian, Bisexual, and Transgender People. New York, Columbia University Press. Retrieved November 28, 2018. from https://journals.sagepub. com/doi/abs/10.1177/1049731506295626
12. Neary, S. (2014): Professional identity: What I call myself defines who I am. Career Matters 2. 3. 14-15. Retrieved October 22, 2018. from https://core.ac.uk/download/pdf/130979824. pdf

13. Norberg, J. R. and Hedenborg, S. (2019): Sweden: a gender perspective on sport governance. In: Elling, A., Hovden, J. and Knoppers, A. (eds.) Gender Diversity in European Sport Governance. Routledge, Abingdon, Oxon. 131-140.

14. Ratcliffe, R. (2013): What's the difference between leadership and management? Guardian. (online). Retrieved November 3, 2018. from https://www.theguardian.com/careers/ difference-between-leadership-management 